\title{
Analisis Kode Etik Jurnalistik Pemberitaan Keberagaman di Media Online
}

\author{
Hana Elga Januari Christi, Farid \\ Hanaelgajc99@gmail.com, Farid@fikom.untar.ac.id \\ Fakultas Ilmu Komunikasi Universitas Tarumanagara
}

\begin{abstract}
The press as a deliver of information not only has the right of freedom of the press but also has a responsibility to apply the ethics journalism to every news presented to the public. Implementing an ethics journalism is something that must be done and considered by every journalist in presenting news specifically about diversity. In Indonesia, an ethics journalism that is often used is a journalistic code of ethics established by the Indonesian Press Council. Therefore this research is about the application of ethics journalism in reporting the issue of diversity on the famous Indonesian online media that is called, detik.com. The purpose of this research is to show the application of ethics journalism among journalists. Applying ethics journalism is important among journalists because that is kind of a guide for journalists in carrying out their work. This research's instruments in this thesis are from coding sheet, the coding sheets filled by two coder. The choice of the coder is based on educational background who takes journalistic studies. The results of this research indicate that detik.com has implemeted the journalistic code of ethics, but 13 of 40 news stories that have been posted, have no element of balance.
\end{abstract}

Keywords: content analysis, diversity, ethics journalism.

\begin{abstract}
Abstrak
Pers sebagai penyampai informasi tidak hanya memiliki hak kemerdekaan pers tetapi juga memiliki tanggung jawab dalam menerapkan kode etik jurnalistik pada setiap berita yang disajikan kepada masyarakat. Menerapkan kode etik jurnalistik adalah sebuah hal yang wajib diperhatikan dan dilakukan oleh setiap wartawan dalam menyajikan pemberitaan khususnya pemberitaan mengenai keberagaman. Di Indonesia, kode etik jurnalistik yang sering digunakan ialah kode etik jurnalistik yang ditetapkan oleh Dewan Pers. Maka dari itu, penelitian ini mengangkat tentang penerapan kode etik jurnalistik pada pemberitaan isu keberagaman pada portal berita online, detik.com. Penelitian ini menggunakan pendekatan kuantitatif dengan sifat deskriptif dan analisis isi sebagai teknik analisis data. Tujuan penelitian ini adalah untuk menunjukkan penerapan kode etik jurnalistik di kalangan wartawan. Menerapkan kode etik jurnalistik adalah hal yang penting di kalangan wartawan karena kode etik jurnalistik adalah pedoman bagi wartawan dalam melaksanakan pekerjaanya. Instrumen yang digunakan pada penelitian ini berupa lembar coding yang diisi oleh dua orang coder. Pemilihan coder berdasarkan latar belakang pendidikan yaitu menempuh studi jurnalistik. Hasil penelitian ini menunjukkan bahwa detik.com telah menerapkan kode etik jurnalistik, namun masih ada berita yang tidak memiliki unsur keberimbangan.
\end{abstract}

Kata Kunci: analisis isi, keberagaman, kode etik jurnalistik. 


\section{Pendahuluan}

Pers sebagai penyampai informasi kepada publik memiliki kebebasan yang disebut dengan 'Kemerdekaan Pers'. Dewan Pers (2011) mendefinisikan bahwa kemerdekaan pers merupakan sarana masyarakat untuk memperoleh informasi dan berkomunikasi, guna memenuhi kebutuhan hakiki dan meningkatkan kualitas kehidupan manusia. Walaupun memiliki kebebasan menyampaikan informasi, pers juga memiliki tanggung jawab untuk menerapkan kode etik jurnalistik dalam menyajikan sebuah pemberitaan, termasuk dalam pemberitaan mengenai keberagaman.

Setiap wartawan baik dari perusahaan media konvensional, cetak, atau pun online harus memperhatikan dan menerapkan kode etik jurnalistik pada setiap pemberitaan yang disajikan kepada masyarakat. Penelitian ini berfokus pada penerapan etika jurnalisme online. Pengertian jurnalisme online menurut pendapat Musman dan Mulyadi (2017) adalah proses penyampaian informasi atau pesan yang menggunakan internet sebagai medianya. Terdapat lima prinsip jurnalisme online menurut Bradshaw dalam Romli (2018) yaitu keringkasan, kemampuan beradaptasi, dapat dipindai, interaktivitas, komunitas dan percakapan.

Setiap berita yang dituliskan oleh wartawan harus memiliki nilai berita. Terdapat nilai-nilai berita yang harus diperhatikan atau setidaknya terdapat tujuh nilai berita menurut Askurifai Baksin yang perlu menjadi perhatian bagi para wartawan: berita harus memiliki kesegaran waktu (timeless), kejadian yang diberitakan memiliki dampak terhadap orang banyak (impact), kejadian yang diberitakan harus menyangkut suatu lembaga atau seseorang yang diketahui orang banyak (prominence), peristiwa yang diberitakan memiliki kedekatan kepada khalayak secara emosional ataupun geografis (proximity), suatu peristiwa atau kejadian yang dituliskan harus memiliki suatu konflik (conflict), pemberitaan mengenai suatu peristiwa atau kejadian yang jarang terjadi di kehidupan sehari-hari (the unusual), dan pemberitaan mengenai halhal yang sedang menjadi bahan pembicaraan orang banyak (the currency) (Musman dan Mulyadi : 2017)

Setiap profesi memiliki landasan moralnya masing-masing, begitu pula seorang wartawan. Wartawan dalam menjalankan tugasnya untuk menyebarkan sebuah informasi dan berita haruslah menerapkan landasan moral. Landasan moral yang harus dipegang dan juga diterapkan oleh wartawan sering disebut dengan kode etik jurnalistik.

Dalam dunia pers, kode etik memegang peran penting yakni sebagai pedoman nilai-nilai bagi para wartawan dalam melaksanakan tugasnya. Tujuan utama jurnalisme adalah menyediakan informasi kepada masyarakat. Maka dari itu setiap wartawan harus mematuhi kode etik jurnalistik yang telah ditetapkan oleh Dewan Pers.

Menurut Marcelino, etika jurnalistik tidak hanya sebagai standar aturan perilaku dan moral para jurnalis dalam melaksanakan pekerjaannya. Etika jurnalistik juga melindungi atau menghindarkan masyarakat dari kemungkinan dampak yang dapat merugikan dari tindakan atau perilaku dari jurnalis yang bersangkutan. (Gawi, Aminulloh, Yasak : 2017)

Di Indonesia, setiap wartawan memiliki tanggung jawab untuk menerapkan kode etik jurnalistik. Kode etik jurnalistik yang menjadi pedoman hampir seluruh wartawan di Indonesia adalah kode etik jurnalistik yang ditetapkan oleh Dewan Pers. Terdapat sebelas pasal yang ditetapkan oleh Dewan Pers. Tiga diantaranya ialah 
mengenai profesionalisme, objektivitas, dan tidak memberitakan mengenai diskriminasi berdasarkan suku, agama, ras, dan antar golongan.

Dalam memberitakan isu keberagaman, wartawan memberitakan berdasarkan fakta atau realitas dari beberapa sudut pandang, memberikan kesempatan pemberitaan yang sama kepada setiap pihak yang relevan dan memastikan secara langsung mengenai informasi yang akan diberitakan (Loisa, Susanto, Junaidi, Loekman, 2019)

\section{Metode Penelitian}

Penelitian ini menggunakan pendekatan kuantitatif dengan sifat deskriptif. Dalam menganalisis data, peneliti menggunakan analisis isi kuantitatif. Neuendorf dalam Eriyanto (2011) mengemukakan bahwa analisis isi adalah sebuah peringkasan (summarizing), kuantifikasi dari pesan yang didasarkan pada metode ilmiah (diantaranya objektif-intersubjektif, reliabel, valid, dapat digeneralisasikan, dapat direplikasi dan pengujian hipotesis) dan tidak dibatasi untuk jenis variabel tertentu atau konteks di mana pesan dibentuk dan ditampilkan. Unit analisis pada penelitian ini adalah pemberitaan mengenai Ustaz Abdul Somad di media online detik.com, yang diunggah pada 18 Agustus - 30 Agustus 2019 lalu.

Kategorisasi pada penelitian ini diturunkan berdasarkan pasal 2, 3, dan 8 Kode Etik Jurnalistik. Adapun kategorisasi penerapan kode etik jurnalistik pada pemberitaan mengenai Ustaz Abdul Somad adalah sebagai berikut:

\section{Menempuh Cara Profesional}

Membuat berita berdasarkan fakta dan menyertai sumber yang jelas.

2. Tidak Bersikap Diskriminasi

Tidak membuat berita yang berisi menyudutkan salah satu pihak berdasarkan suku, agama, ras, dan antar golongan.

3. Memberitakan Secara Berimbang

Apabila berita tersebut tidak hanya berisikan sudut pandang dari satu pihak, melainkan juga dari pihak lainnya.

4. Sumber berita yang relevan

Apabila berita berisikan pernyataan dari narasumber yang relevan dengan judul berita yang dituliskan.

5. Tidak Mencampurkan Fakta dan Opini

Tidak mencampurkan fakta dan opini yaitu terdapat kata: menurut saya, alangkah lebih baik, seharusnya.

Populasi dan sampel penelitian ini adalah berita tentang Ustaz Abdul Somad di detik.com. Jumlah populasi sebanyak delapan puluh satu (81) berita, yang diunggah dalam rentang waktu 18 Agustus - 30 Agustus 2019. Dengan jumlah populasi yang ada, penarikan jumlah sampel menggunakan teknik simple random sampling. Jumlah sampel dipilih secara acak tanpa memperhatikan strata pada populasi tersebut karena setiap sampel memiliki kesempatan yang sama. Dari 81 populasi berita, dipilih 40 berita yang akan dijadikan sampel untuk penelitian ini.

Dalam penelitian ini menggunakan uji reliabilitas berdasarkan formula Holsti, dengan rumus:

$$
\text { Reliabilitas Antar-Coder: } \frac{2 M}{N 1+N 2}
$$

Di mana $\mathrm{M}$ adalah jumlah coding yang sama (persetujuan) oleh masingmasing coder, N1 adalah jumlah coding yang dibuat coder 1, dan N2 adalah jumlah coding yang dibuat oleh coder 2 . Reliabilitas bergerak dari angka 0 hingga 1 , di mana 
0 berarti tidak ada satupun persetujuan dan 1 berarti persetujuan sempurna antar coder. Dalam Formula Holsti, angka reliabilitas dapat ditoleransi minimal 0,7 atau 70\%

\section{Hasil Temuan dan Diskusi}

Setelah dilakukan perhitungan frekuensi penerapan kode etik jurnalistik pada pemberitaan mengenai Ustaz Abdul Somad, peneliti selanjutnya melakukan rekapitulasi (ringkasan) dan perbandingan antar dua coder menggunakan rumus formula Holsti. Reliabilitas dengan menggunakan formula Holsti menunjukkan persentase persetujuan, berapa besar persentase persamaan antar coder ketika menilai suatu isi. Hasil perhitungan uji reliabilitas sebesar 0,8 atau $80 \%$ dari 40 berita yang akan diteliti. Adapun pembahasan dari masing-masing kategori yaitu:

Tabel 1. Menempuh Cara Profesional

\begin{tabular}{ll}
\hline Kategori & Persentase \\
\hline Setuju & $\mathbf{1 0 0 \%}$ \\
\hline Tidak Setuju & - \\
\hline Total & $\mathbf{1 0 0 , 0 \%}$ \\
\hline
\end{tabular}

Berdasarkan Tabel 1 di atas, dapat dilihat bahwa detik.com sebagai portal media online menerapkan kode etik jurnalistik. Detik.com dalam menyajikan pemberitaan mengenai Ustaz Abdul Somad yang diduga melakukan penghinaan simbol agama menempuh cara-cara profesional pada seluruh berita, yaitu dengan 40 frekuensi atau $100 \%$.

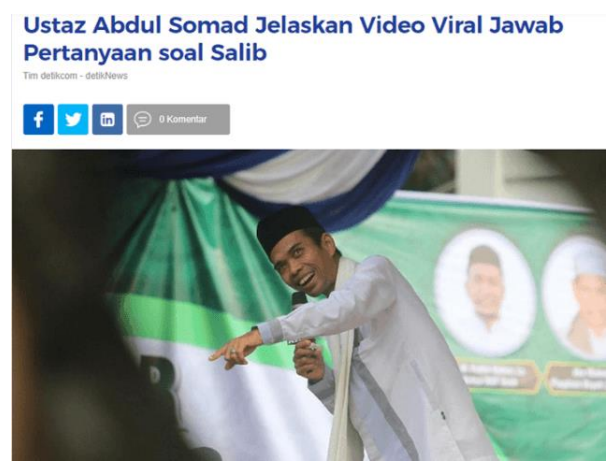

"Video penjelasan UAS ini kemudian diunggah oleh akun YouTube FSRMM TV pada Minggu (18/8) dengan judul 'Klarifikasi Tentang Anggapan Ustadz Abdul Somad Menghina Kristen / Menghina Salib'."

Seperti yang dilihat pada kutipan berita di atas, dalam menyebarkan pemberitaan mengenai penjelasan Ustaz Abdul Somad terkait dugaan penghinaan simbol agama, detikcom membuat berita berdasarkan fakta dan menyertai sumber yang jelas. Dalam hal ini detikcom mendapatkan informasi melalui video penjelasan Ustaz Abdul Somad yang diunggah pada akun Youtube FSRMM TV pada 18 Agutus 2019 lalu. 
Hana Elga Januari Christi, Farid: Analisis Kode Etik Jurnalistik Pemberitaan Keberagaman di Media Online

Tabel 2. Tidak Bersikap Diskriminasi

\begin{tabular}{cc}
\hline Kategori & Persentase \\
\hline Ya & $77.5 \%$ \\
\hline Tidak & $22,5 \%$ \\
\hline Total & $100,0 \%$ \\
\hline
\end{tabular}

Pada Tabel 2 menunjukkan bahwa detik.com dalam membuat berita mengenai pemberitaan Ustaz Abdul Somad masih terdapat berita yang memiliki unsur diskriminasi. Dari empat puluh (40) berita yang diteliti, frekuensi berita yang dituliskan oleh wartawan detikcom sebanyak 31 atau 77,5\%.

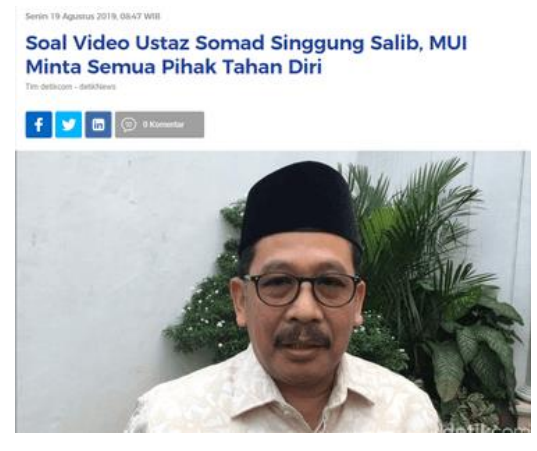

Berdasarkan isi yang ada dalam pemberitaan tersebut, wartawan detik.com menuliskan berita dengan tidak bersikap diskriminasi yang menyudutkan satu pihak berdasarkan suku, agama, ras, dan antar golongan. Terbukti dengan adanya tulisan sebagai berikut:

"Terkait masalah yang menimpa UAS, Zainut mengimbau semua pihak untuk mengedepankan semangat persaudaraan. Musyawarah harus diutamakan dalam menangani masalah tersebut."

Tabel 3. Memberitakan Secara Berimbang

\begin{tabular}{ll}
\hline Kategori & Persentase \\
\hline Setuju & $67,5 \%$ \\
\hline Tidak Setuju & $32,5 \%$ \\
\hline Total & $100,0 \%$ \\
\hline
\end{tabular}

Berdasarkan Tabel 3 di atas, menunjukkan bahwa detik.com dalam menuliskan berita mengenai Ustaz Abdul Somad terkait kasus penghinaan simbol agama menerapkan unsur keberimbangan. Dari 40 berita yang ada, terdapat 27 frekuensi atau $67,5 \%$ berita yang mengandung unsur keberimbangan.

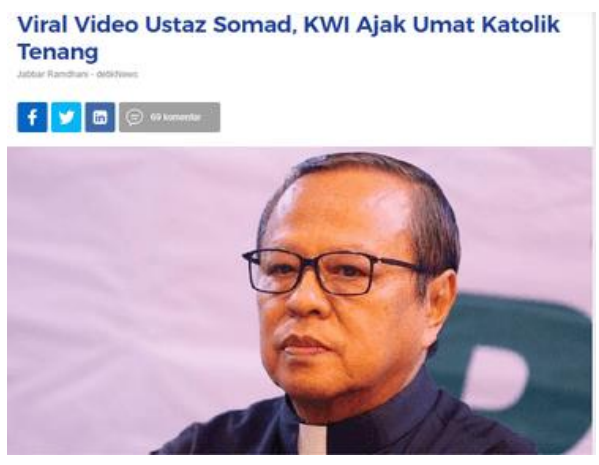


"Sudah banyak yang memberi catatan, termasuk dari sahabat-sahabat muslim sendiri. Saya sendiri mengajak umat Katolik untuk tidak usah menanggapi," kata Ketua KWI Mgr Ignatius Suharyo, Senin (19/8/2019)."

"Sebelumnya, soal video UAS yang viral, banyak pihak yang menanggapi. Majelis Ulama Indonesia (MUI) meminta semua pihak menahan diri dan tidak terprovokasi video UAS yang menjawab jemaah soal salib. MUI menyarankan tokohtokoh agama untuk arif dalam menyampaikan pesan-pesan keagamaan. Sehingga tidak ada perasaan umat lain yang tersakiti”

Tabel 4. Sumber Berita Yang Relevan

\begin{tabular}{ll}
\hline Kategori & Persentase \\
\hline Setuju & $\mathbf{1 0 0 , 0 \%}$ \\
\hline Tidak Setuju & - \\
\hline Total & $\mathbf{1 0 0 , 0 \%}$ \\
\hline
\end{tabular}

Tabel 4 menunjukkan frekuensi untuk kategori sumber yang relevan sebanyak 40 frekuensi atau $100 \%$. Artinya, detik.com menyertai sumber yang relevan untuk seluruh berita Ustaz Abdul Somad yang dikabarkan menghina salah satu simbol agama. Sumber berita relevan yang dimaksud dalam hal ini ialah narasumber yang sesuai dan cocok dengan judul dan peristiwa yang terjadi.

Berita yang berjudul "Lembaga Adat Melayu Nilai Ceramah UAS Soal Salib Tak Penuhi Unsur Pidana" menjadi salah satu berita yang menyertakan sumber yang relevan pada portal media online detik.com. pada berita tersebut bertuliskan:

"Memang UAS dilaporkan (ke pihak kepolisian). Kita melihat tidak ada unsur pidananya, karena yang menyebarkan video tersebut bukan UAS. Kemudian ceramah UAS itu kan di dalam masjid pada komunitas umat muslim," kata pengacara LBH LAM Riau, Aziun Azhari dalam perbincangan dengan detikcom, Rabu (21/8/2019)."

Tabel 5. Tidak Mencampurkan Fakta dan Opini

\begin{tabular}{lc}
\hline \multicolumn{1}{c}{ Kategori } & Persentase \\
\hline Setuju & $\mathbf{7 2 . 5 \%}$ \\
\hline Tidak Setuju & $\mathbf{2 7 , 5 \%}$ \\
\hline Total & $\mathbf{1 0 0 , 0 \%}$ \\
\hline
\end{tabular}

Hasil penelitian berdasarkan Tabel 5 menunjukkan bahwa dari 40 berita tentang Ustaz Abdul Somad yang diduga menghina salah satu simbol agama menujukkan bahwa mayoritas berita $(72,5 \%)$ detik.com dalam penulisannya tidak mencampurkan fakta dan opini, dan hanya sedikit berita $(27,5 \%)$ yang dalam penulisannya mencampurkan fakta dan opini. 


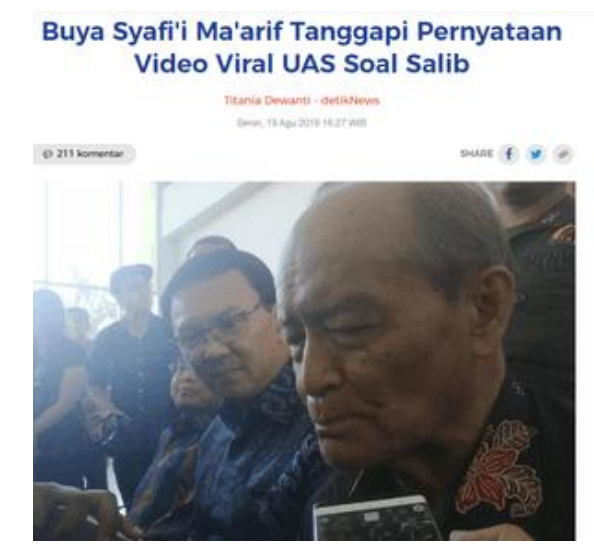

Berita di atas menjadi salah satu berita yang disajikan oleh detik.com tanpa mencampurkan fakta dan opini dari wartawan itu sendiri. Di dalam berita tersebut terdapat tulisan sebagai berikut:

"Seperti diketahui, video UAS yang membahas tentang salib beredar di medsos. UAS mengaku heran video pengajiannya yang menjawab pertanyaan jemaah soal salib menjadi viral. UAS menyebut pengajiannya itu dilakukan sekitar tiga tahun lalu."

\section{Simpulan}

Berdasarkan hasil penelitian terhadap pemberitaan isu keberagamaan pada portal berita online detik.com, dengan unit analisis pemberitaan mengenai Ustaz Abdul Somad yang diduga menghina salah satu simbol agama. Disimpulkan bahwa detik.com sebagai salah satu media online ternama di Indonesia telah menerapkan kode etik jurnalistik. Terlihat dari hasil analisis isi kuantitatif dengan menggunakan lima kategorisasi yaitu menempuh cara profesional, tidak bersikap diskriminasi, memberitakan secara berimbang, sumber yang relevan, dan tidak mencampurkan fakta dan opini. Namu dari lima kategorisasi tersebut, satu kategori "memberitakan secara berimbang" memiliki frekuensi paling rendah yaitu sebesar $67,5 \%$ dibandingkan dengan empat kategori yang lainnya. Dari 40 berita yang disajikan, 27 berita yang dituliskan secara berimbang atau terdapat 13 berita yang tidak dituliskan secara berimbang.

\section{Ucapan Terima Kasih}

Peneliti mengucapkan banyak terimakasih kepada seluruh pihak yang membantu dalam penulisan jurnal ini dan semua pembaca yang telah membaca jurnal ini.

\section{Daftar Pustaka}

Eriyanto. (2011). Analisis Isi: Pengantar Metodologi Untuk Penelitian Ilmu Komunikasi dan Ilmu-Ilmu Sosial Lainnya, Edisi Pertama. Jakarta: Kencana

Gawi, Gabriel. Aminulloh, Akhirul. Yasak, Ellen Meianzi. (2017). Penerapan Kode Etik Jurnalistik Dalam Surat Kabar Harian Surya Malang. JISIP Universitas Tribhuwana Tunggadewi Malang. Retrieved From Loisa, Riris. Susanto, Eko Harry. Junaidi, Ahmad. Loekman, Felicia. (2019). Media Siber, Aparat, 
dan Pemberitaan Keberagaman. Jurnal ASPIKOM Vol 3 No.6 hlm.

Retrieved From http://jurnalaspikom.org/index.php/aspikom/article/view/434/179

Musman, Asti., \& Mulyadi, Nadi. (2017). Jurnalisme Dasar Panduan Praktis Para Jurnalis, Edisi 1. Yogyakarta: Komunika

Romli, Asep Syamsul M. (2018). Jurnalistik Online Panduan Mengelola Media Online, Edisi II. Bandung: Nuansa Cendikia.

https://publikasi.unitri.ac.id/index.php/fisip/article/view/366 